\title{
KAJIAN LIVING AL-HADITS ATAS TRADISI SHALAT BERJAMA'AH MAHGRIB-ISYA` DI RUMAH DUKA 7 HARI DI DUSUN NUGUK, MELAWI, KALIMANTAN BARAT
}

\author{
Wendi Parwanto \\ Alumni Jurusan Ilmu Al-Qur`an dan Tafsir IAIN Pontianak \\ Mahasiswa Pascasarjana UIN Sunan Kalijaga, Yogjakarta \\ wendipurwanto04@gmail.com
}

\begin{abstract}
ABSTRAK
The analysis used in this study is Karl Mannheim's sociology of knowledge, especially on three aspects of meaning: Objective meaning, expressive meaning and documentary meaning. The results of this study are: 1) Objective Meanings, all people believe that the traditions they do are inherited from their predecessors; 2) Meaning of Expression, they believe in fadhilah by reciting yasin and tahlil can help the body in the grave; and, 3) Documentary Meanings, they do not realize the meaning implied or hidden in the tradition, so that the actor or actor does not realize that what he is doing is an expression that shows the culture as a whole.

(Analisis yang digunakan dalam penelitian ini adalah teori sosiologi pengetahuan Karl Mannheim, terutama pada tiga aspek makna: Makna objektif, makna ekspresif dan makna dokumenter. Hasil dari penelitian ini adalah: 1) Makna Objektif, semua masyarakat meyakini bahwa tradisi yang mereka lakukan adalah warisan dari pada pendahulu mereka; 2) Makna Ekspresi, mereka meyakini fadhilah dengan dibacakan yasin dan tahlil dapat menolong mayat di alam kubur; dan, 3) Makna Dokumenter, mereka tidak menyadari makna yang tersirat atau tersebunyi di dalam tradisi tersebut, sehingga aktor atau pelaku tindakan tidak menyadari bahwa apa yang dilakukannya itu merupakan suatu ekspresi yang menunjukan kepada kebudayaan secara keseluruhan).
\end{abstract}

Kata Kunci: Tradsi Kematian, dusun Nuguk

\section{Pendahuluan}

Indonesia merupakan negara yang majemuk, baik dari segi keyakinan/agama (religion), bahasa (languange), adat/tradisi (tradition) dan termasuk kerpercayaan lokal (local faiths). ${ }^{1}$ Islam merupakan agama mayoritas di Indonesia, dan di

\footnotetext{
1 Tim Penerjemah, Al-Qur`an dan Terjemah Bahasa Dayak Kanayatn, (Jakarta : Puslitbang LKK Badan Litbang dan Diklat Kementerian Agama RI, 2015), v-vii
}

dalam Islam itu sendiri sampai sekarang masih banyak menyimpan ritus-ritus peralihaan $^{2}$ atau ritus-ritus lokalitas - yang

${ }^{2} \mathrm{Di}$ antara penelitian tentang ritus peralihan di Indonesia secara umum adalah : Erni Budiwanti, Islam Sasak: Wektu Telu Versus Waktu Lima (Yogjakarta : LkiS, 2000) ; Koentrajaningrat, Ritus Peralihan di Indonesia, cet. 2 (Jakarta : Balai Pustaka, 1993); Suwito, (dkk). Tradisi Dan Ritual Kematian Wong Islam Jawa (Jurnal Kebudayaan Islam, vol. 13, no. 2. Juli - Desember, 2015, IAIN Purwokerto) dan ; Moh. Khairuddin, Tradisi Slametan Kematian dalam Tinjauan Hukum Islam 
menurut beberapa asumsi bahwa beberapa praktik ritus keagamaan tersebut merupakan akultulturasi dari budaya-budaya agama sebelumnya. Tersmasuk ritus kematian, dalam ritus kematian di Indonesia pun di setiap daerah memiliki pola serta praktik pemaknaanyang beragaman. Mulai peringatan 3, 7, 40, 100, dan 1000 hari kematian dan dalam praktik ritual di dalamnya pun memiliki perbedaan, ada yang memperingati dengan membacakan yasin dan tahlil, ada juga yang menggunkan tadarusan al-Qur`an, kemudian ada juga dengan membaca ayat tertentu dengan jumlah tertentu, dan sederetan praktik keyakinan yang dilakukan lainnya. ${ }^{3}$ Demikian dalam realitas masyarakat di Dusun Nuguk, Melawi, Kalimantan Barat, masyarakat setempat juga melakukan ritus kematian yang memang cukup unik, yaitu dengan menggelar shalat mahgrib dan isya` secara berjamaah selama 7 hari di rumah orang yang berduka cita tersebut dengan tujuan untuk mendo'akan orang yang telah meninggal dunia dan juga untuk

dan Budaya, (Jurnal Penelitian Keislaman, vol. 11, no. 2, Juli 2015, UIN Syarif Hidayatullah Jakarta)

${ }^{3} \mathrm{Di}$ antara penelitian tentang ritus peralihan dalam kematian: Widyawati, Pembacaan 100.000 Kali Surat Al-Ikhlas Dalam Ritual Kematian Di Jawa (Rw. 03 Kelurahan Pulutan, Sidorejo, Salatiga, Jawa Tengah), Skripsi,Fakultas Ushuluddin dan Pemikiran Islam, UIN Sunan Kalijaga Yogjakarta, 2017 dan Ibrizatul Ulya, Pembacaan 124.000 Kali Surat Al-Ikhlas Dalam Ritual Kematian Di Jawa (Stusi Kasus di Desa Sungonlegowo, Bungah, Gresik, Jawa Timur), Skripsi, Fakultas Ushuluddin dan Pemikiran Islam, UIN Sunan Kalijaga Yogjakarta. menghibur pihak keluarga yang ditinggalkan, dan pola serta praktik ritus kematian seperti ini belum penulis temukan di daerah lain, bahkan di dusun sebelahnya - mereka tidak melakukan ritus seperti itu. Oleh karena itu, berdasarkan ilustrasi singkat tersebut maka dirasa penting topik ini untuk dibahas.

Adapun fokus kajian dalam penelitian ini adalah melihat bagaimana deskrispsi pelaksanaan dari tradsi shalat berjamaah maghrib-isya di rumah duka selama 7 hari di dusun Nuguk, Melawi, Kalimantan barat tersebut, termasuk melihat literatur turast yang dijadikan landasan, serta berusaha melihat struktur genealogi pemikiran atau proses tranmisi tradisi sehingga tradisi tersebut bisa terbentuk. Dan terakhir, melihat bagaimana praktik tradisi tersebut dengan kacamata sosiologi pengetahuan Karl Mannheim.

Kerangkan teori yang digunakan dalam penelitian ini adalah dengan menggunkan 'pisau analisis' sosiologi pengetahuan Karl Mannheim, yang difokuskan pada tiga variabel, yaitu dilihat dari: Pertam, Makna Objektif adalah makna yang ditentukan oleh konteks sosial dimana tindakan tersebut berlangsung ; Kedua, Makna Ekspresif adalah makna yang ditunjukan oleh aktor (pelaku tindakan); dan Ketiga, Makna Dokumenter adalah makna yang tersirat atau tersem- 
bunyi, sehingga (aktor) pelaku tindakan tersebut, tidak sepenuhnya menyadari bahwa suatuaspek yang diekspresikan menunjukkan kepada kebudayaansecara keseluruhan. $^{4}$

Kemudian, instrumen penelitian yang digunakan dalam penelitian ini adalah dengan menggunaka metode kualitatif yaitu menitik beratkan pada kualitas data bukan pada kauntitas data $^{5}$, kemudian sifanya studi lapangan (field research), dan dengan pola analisis diskriptif-analisis, yaitu dengan mengeksplorasi data secara apa adanya setelah itu melakukan analisis dengan 'pisau analisis' yang telah disebutkan di atas. Selanjutnya, metode pengumpulan data dalam penelitian ini adalah dengan melakukan wawacara (interview) ${ }^{6}$ via telepon kepada narasumber utama serta beberapa narasumber pendukung lainnya, termasuk juga melacak beberapa literatur penelitian senanda lainnya sebagai studi banding dalam penelitian ini.

\footnotetext{
${ }^{4}$ Gregory Baum, Agama dalam bayangbayang relativisme : Agama, Kebenaran dan Sosiologi Pengetahuan, terj. Ahmad Murtajib Chaeri dan Asyhuri Arow (Yogyakarta : PT. Tiara Wacana Yogya, 1999), hlm. 15-16 ; Muhyar Fanani, Metode Studi Islam : Aplikasi Sosiologi Pengetahuan Sebagai Cara Pandang (Yogyakarta : Pustaka Pelajar, 2008), hlm 59.

${ }^{5} \mathrm{M}$. Hariwijaya, Metodologi Teknik penulisan Skripsi, Thesis dan Disertasi. (Yogjakarta : Almatera Publishing, . 2007), hlm. 71.

${ }^{6}$ Heri Jauhari, Panduan Penulisan Skripsi Teori dan Aplikasi. Bandung : Pustaka Setia , 2010), hlm. 132.
}

Tradisi Shalat Berjama'ah di Rumah yang Berduka Selama 7 Hari di Dusun Nuguk, Kabupaten Melawi, Kalimantan

\section{Barat}

\section{Layout Geografi Dusun Nuguk}

Dusun Nuguk merupakan salah satu dusun yang berada di Kabupaten Melawi. Perlu diketahuai bahwa jarak tempuh dari kota provinsi Kalimantan Barat (Pontianak) ke kabupaten Melawi adalah 515,2 Km, dengan perjalanan yang menyita waktu lebih kurang 10-11 jam. Kabupaten Melawi ini terdiri 7 kecamatan, 82 desa, 292 dusun, yang kemudian dilakukan pemekaran beberapa kecamatan baru yang dibentuk berdasarkan Peraturan Daerah (Perda) Nomor 32 Tahun 2007 Tentang Pembentukan Kecamatan Pinoh Utara, Kecamatan Pinoh Selatan, Kecamatan Belimbing Hulu dan Kecamatan Tanah Pinoh Barat, sehingga sekarang ini kabupaten Melawi terdiri dari 11 kecamatan, 169 desa dan 525 Dusun. Dari 11 kecamatan yang ada di kabupaten Melawi, ada kecamatan yang bernama Kecamatan Pinoh Utara yang membawahi beberapa desa, salah satunya yaitu desa Tebing Karangan. Desa Tebing Karangan ini merupakan desa yang masih tergolong baru di kabupaten Melawi. Desa ini memba- 
wahi beberapa dusun, salah satunya adalah Dusun Nuguk. ${ }^{7}$

Dusun Nuguk merupakan dusun yang terangkum dalam naungan Kecamatan Nanga Pinoh, Kabupaten Melawi. Jarak dari pusat kota Nanga Pinoh ke dusun Nuguk sekitar $50 \mathrm{~km}$, dan bisa ditempuh melalui dua alternatif : jalur air dan jalur darat. Jika melawati jalur air maka dapat menyita waktu kurang lebih 3 jam, namun jika menggunakan jalur darat dapat ditemput dengan waktu sekitar 1 jam, dan akses jalan yang dirasa kurang layak untuk dilalui, terutama jika musim hujan, karena jalan tersebut belum di semen atau belum dibari batu apalagi di aspal, jalan untuk masuk ke dusun tersebut masih berupa jalan tanah biasa, sehingga jika musim penghujan orangorang lebih memilih jalur air dari pada jalur darat. ${ }^{8}$ Kondisi sosial keagamaan di Dusun Nuguk - masyarakatnya 100\% Muslim. Dan dari sektor pendidikan, masyarakat Dusun Nuguk masih tergolong sangat minim dalam hal kualitas sumber daya manusia, karena yang yang bisa menyelesaikan SD/ sederajat hanya 22 orang, SMP/

\footnotetext{
${ }^{7}$ Buku Pedoman Desa Tebing Karangan, tahun 2017, hlm. 7 .

${ }^{8}$ Buku Pedoman Desa Tebing Karangan, tahun 2017, hlm. 9-10.
}

sederajat 4 orang dan SMA/sederajat 4 orang. ${ }^{9}$

\section{Deskripsi Tradisi}

Tradisi 'Shalat Berjamaah Mahgrib-Isya di Rumah Yang Berduka selama 7 hari' di Dusun Nuguk, Melawi, Kalimantan Baratadalah salah satu tradisi yang telah mengakar di masyarakat Dusun Nuguk. Tidak ada keterangan yang jelas tentang kapan tradisi ini dimulai. Menurut keterangan masyarakat setempat bahwa tradisi ini sudah ada sejak zaman dahulu - dan bahkan para tokoh elite agama mereka (sesepuh) mereka pun tidak mengetahui kapan tradisi ini bermula. ${ }^{10}$ Sebagaimana dimaklumi bahwa masyarakat pedalaman biasanya banyak menyimpan ritus-ritus keagamaan yang mungkin masih eksis sampai sekarang salah satunya adalah tradisi 'Shalat Berjamaah Maghrib-Isya di Rumah Duka', sebuah ritus peralihan yang ada di Dusun Nuguk. ${ }^{11}$

Prosesi tradisi pada lingkaran milieu masyarakat Dusun Nuguk, jika

${ }^{9}$ Buku Pedoman Desa Tebing Karangan, tahun 2017, hlm. 12.

${ }^{10}$ Wawancara dengan Bpk. Murni, Sabtu, 03 Maret 2018 (Pukul. 20.00 WIB) via. Telpon, beliau dianggap sepuh pada masyarakat setempat.

${ }^{11}$ Tradisi ini mungkin ada di daerah lain dengan nama yang berbeda. Karena masyarakat Nusantara merupakan masyarakat yang multikultural - terutama masyarakat yang berada di pedalaman, dan pasti banyak menyimpan kekayaan tradisi yang telah diwarisi turun-temurun dari pendahulu mereka. 
ada warga yang meninggal dunia maka warga yang lainnya memberikan sedekah yang biasa dengan memberikan beras $2 \mathrm{Kg}$, garam, gula dan kelapa. Prosesi tradisi kematian di Dusun Nuguk layaknya mengadakan sebuah pesta, masyarakat berkumpul membuatdengan berbagai tugas masing-masing, misalnya Ibu-ibu bertugas memasak, membuat serabi dan petura,12 dan bapak-bapak ditugasnya mencari kayu bakar untuk memasak. Kemudian setelah prosesi penguburan dilakukan, maka pada malam harinya masyarakat melaksanakan shalat maghrib dan isya' berjamaah di rumah duka selama 7 hari, dan tepatnya pada hari ke 7, pihak keluarga yang ditinggalkan menyedekahkan pakaian orang yang meninggalkan tersebut kepada warga sekitar, terutama kepada pihak yang mengurus jenazah. Kemudian mengapa mereka memilih shalat di rumah duka? Salah satu keterangan mengatakan bahwa, selain untuk memperat silaturrahmi juga tujuannya adalah untuk menghibur keluarga yang ditinggalkan. Sebagaimana yang diungkpakan oleh Pak Murni :

"Tujuane je ke no'okan mayat dan ke menyamong tali saudara sesamo kito, dan ke ngingat jaso mayat selama yo

\footnotetext{
${ }^{12}$ Petura' adalah kue yang dibungkus dengan daun pisang dan dibuat seperti mayat yang dibalut dengan kain kafan.
}

meninggalkan dunio tuk (Tujuan dari tardisi ini adalah untuk mendo'kan mayat, memperat jalinan silaturrahmi dan untuk mengingat jasa orang yang meninggal tersebut). ${ }^{13}$

Kemudian mengapa hanya memilih berjamaah pada shalat maghrib dan isya saja, hal ini mungkin karena hanya pada itu masyarakat bisa hadir dan berkumpul, sedangkan dari pagi sampai sore masyarakat Dusun Nuguk berada di ladang, karena mayoritas masyarakat di sana hidupnya bertani. ${ }^{14}$ Pada waktu maghrib dan isya masyarakat berkumpul di rumah duka untuk melaksanakan shalat berjamaah layaknya sholat yang dilakukukan di masjid, mulai dari adzan, wiridan bersama setelah shalat hingga bersalaman. Setelah shalat maghrib dilaksanakan, maka dilanjutkan dengan membaca surat yasin yang dipimpin oleh seorang pemuka agama di dusun tersebut ${ }^{15}$ dengan disuguhkan beberapa makanan ringan, seperti kue serabi, petura' dan kopi atau teh.

\footnotetext{
${ }^{13}$ Wawancara dengan Bpk. Murni, Sabtu, 03 Maret 2018 (Pukul. 20.00 WIB) via. Telpon.

${ }^{14}$ Model petani disana bukan seperti masyarakat di daerah Jawa, yang bertani di sawah, namun di Dusun Nuguk bertaninya dengan menebang hutan - rimba, yang sering di kenal dengan 'Ladang Berpindah' sehingga pengerjaan membutuhkan waktu yang lama, dan panennya hanya satu kali dalam setahun.

${ }^{15}$ Tidak ada nama yang jelas bagi pemuka agama di Dusun Nuguk, misalnya sebutan "Rohis" dalam masyaraka Jawa, dan di masyarakat Dusun Nuguk tokoh elite agama tersebut biasanya dikenal dengan sebutan 'Pengurus Fardhu Kifayah'.
} 
Tradisi tahlil dan membaca yasin seperti ini sebagaimana kita ketahui bahwa tradisi membaca surah yaasiin memang tekah banyak dipakai di hampir seluruh daerah di Indonesia salah satunya sama halnya dengan yang dilakukan oleh orang Jawa, yang mana terdapat juga tradisi membaca surat Yasin setiap malam jum'at yang dikhususkan untuk ahli kubur/ orangorang yang telah meninggal, dengan tujuan berdoa untuk memohonkan ampunan bagi arwah ahli kubur agar mendapatkan temapat yang baik di sisiNya yaitu masuk ke dalam surga-Nya. Kemudian ada juga tradisi menyelenggarakan acara arwahan pada bulan Sya'ban yaitu keluarga mengundang masyarakat sekitar untuk datang ke rumah setelah shalat magrib atau setelah shalat Isya' dengan mengadakan acara membaca surah Yasin dan Tahlil yang pahalanya dikhususkan bagi arwah ahli kubur dari keluarganya. ${ }^{16}$

Kemudian setelah tiba waktu isya, masyarakat melaksanakan shalat isya berjamaah dengan prosesi layaknya sholat maghrib. Setelah shalat isya dilaksanakan, dilanjutkan dengan

${ }^{16}$ Abdul Karim, Makna Kematian dalam Perspektif Tasawuf, (Jurnal ESOTERIK, vol. 1, no. 1, Juni 2015, STAIN Kudus Jawa Tengah) hlm. 41. $\operatorname{tahlilan}^{17}$, dan setelah tahlilan dilaksanakan maka masyarakat dihidangkan dengan 'makanan berat' (nasi dan laukpauk).

Sekitar tahun 2000-an, prosesi tradisi tersbut 'agak' berbeda dengan yang ada sekarang terutama acara setelah selesai maghrib dan isya. Setelah melaksanakan shalat maghrib masyarakat melakukan tahlilan dan yasinan, kemudian setelah isya dilanjutkan dengan membaca al-Qur’an, seperti yang dilakukan pada bulan Ramadhn. Namun, prosesi ini terkikis seiring berjalannya waktu, dan diganti dengan prosesi seperti yang telah disebutkan di atas. Suatu tradisi akan berkembang lagi dan menjadi "hukum" atau kode etik di dalam masyarakat. Di dalam suatu kepercayaan masyarakat terhadap "hukum" atau kode etik tadi maka kebiasaan-kebiasaan di dalam masyarakat tersebut akan dilakukan bahkan dilaksanakan. ${ }^{18}$ Ada dua asumsi yang menyebabkan adanya pergeseran prosesi tersebut, sebagaimana yang diungkapkan oleh Pak Murni :

\footnotetext{
${ }^{17}$ Tentang Tahlilan, baca. M. Quraish Shihab, Perjalanan Menuju Keabadian (Tanggerang : Lentera Hati, 2001),hlm. 241 ; Komariddin Hidayat, Psikologi Kematian (Jakarta : Puri Mutiara, 2005), hlm. 153.

${ }^{18}$ I Made Marthana Yusa, Perayaan Kematian dalam Tinjauan Desain dan Gaya Hidup, (Jurnal Studi Kultural, vol. II, no. 2, Juli 2017) hlm. 68.
} 
"Diganti dengan yasin duo tahlel, karno ngeja waktu magreb ke iso nok kok lamat, keduo je golak nok mampu namat kero'an sampai $30 \mathrm{juz}$ dalam wa'tu 7 hari e" (Digantinya tadusan alQur`an dengan yasinan dan tahlil adalah : Pertama, karena mengingat rentang waktu isya dan maghrib tidak begitu panjang maka diganti - cukup dengan membaca yasin, kemudian kedua, setelah isya tidak lagi tadarusan alQur`an dan diganti dengan tahlilan, karena memang biasanya dalam jangka waktu 7 hari tersebut - tidak mampu mengkhatamkan 30 juz dari al-Qur`an. ${ }^{19}$

Hampir senada dengan yang diungkapkan oleh Pak Apong mengapa tadarusan diganti dengan yasinnan dan tahlilan:

"Lolu te memang sompat diadokan tadarus kero`an selopas iso, tapi karno ado yang bemimpi tepat e pas pemati rah kai Dawin, di pemantau dok kaluargo, rowah medah podeh di kubo, karno maco kero ‘n ko ango juz 15, nok sampai tamat, nyom ngoso diganti dengan yasin dan tahlel, tapi btuk sesuai orang yang mpuk ajat am, kalau e nyuroh berjaamh baru datang, akalu inok je inok am" (Dulu memang sempat diadalan tadarusan al-Qur'an $b a^{\prime} d a$ Isya' namun pada waktu itu, tepat ketika hari ke-7 dari meninggalnya arwah Pak Dawin, pihak keluarga bermimpi bahwa arwah Pak Dawin tesebut sakit karena pembacaan alQur`an hanya sampai pada juz 15, dan tidak mempu diselesaikan sampai juz 30, maka sekarang inisitifnya diganti dengan yasin dan tahlil, kemudian terkait berjamaah tersebut, harus diundang dari pihak keluarga, kalau pihak

\footnotetext{
${ }^{19}$ Wawancara dengan Bpk. Murni, Sabtu, 03-03-2018 (Pukul. 20.00 WIB) via. Telpon.
}

keluarga tidak ingin mengadakan, maka tidak diadakan). ${ }^{20}$

Realitas yang cukup unik pada masa-masa awal dari tradisi ini adalah masyarakat cenderung memilih berjamaah di rumah duka dari pada berjamaah di masjid. Dan kerap-kali masjid kosong pada waktu maghrib dan isya setelah ada warga yang meninggal dunia, dan setelah 7 hari shalat mahgrib-isya dilaksanakan di rumah duka, maka pada hari selanjutnya masjid tetap masih sepi, dan bahkan orang-orang yang biasa terlihat shalat di rumah duka, tidak pernah datang berjamaah ke masjid. Ini yang cukup menerik. Namun sekarang, ada salah satu warga yang memiliki pandanga baru, bahwa boleh melaksanakan shalat di rumah duka asalkan masjid tetap ada adzan dan dilaksanakan shalat di dalamnya. Sebagaimana yang diungkapkan oleh Pak Melly:

"Bituk dah ado kaso e, masyarakat walupun semayang di laman dok losi, tapi tetap ado am yang azan di mensiget, nok ubo lolu teh, ko semayang di laman yang losi gono am" (Relaitas sekarang sudah lumayan berbeda, karena walupun ada yang shalat di rumah duka, namun di masjid tetap ada yang shalat, tidak seperti dulu yang hanya diutamakan sholah di rumah duka). ${ }^{21}$

\footnotetext{
${ }^{20}$ Wawancara dengan Pak Apong, Selasa, 06-03-2018 (pukul : 20.30 WIB) via. Telpon.

${ }^{21}$ Wawancara dengan Pak Melly, Minggu, 04-03-20018 (pukul : 20.00 WIB) via. Telpon.
} 
Paradigma baru mungkin akan bermunculan seiring dengan berjalannya waktu dan perkembangan peradaban dengan dipelopori oleh generasi-generasi baru yang mungkin mendapatkan sentuhan dokrin agama serta pengetahuan agama yang memadai di masa mendatang. Kenyataan tetap ditemukannya upacara kematian di masyarakat yang modern merupakan indikator bahwa praktik keagamaan itu oleh pelakunya memang diyakini sebagai praktik keagamaan resmi dalam Islam. Setidaknya, terdapat alasan normatif dari upacara kematian yang dilakukan oleh masyarakat Nahdhiyin yang hidup ditengah arus modernisasi, praktik keagamaan populer oleh masyarakat Islam, yaitu keyakinan bahwa praktik keagamaan itu merupakan bagian dari ajaran agama yang harus dilaksanakan, sehingga upacara kematian, dalam pandangan masyarakat tidak termasuk dalam kategori bid'ah yang dilarang oleh agama. ${ }^{22}$

Namun, hal ini juga mungkin masih sulit dilakukan, terutama untuk merubah suat tradisi yang telah melekat serta 'mendarah-daging' dalam realitas kemasyarakatan. Perlu proses yang

${ }^{22}$ A. Syihabuddin HS, Tradisi Upacara Kematian Pada Masyarakat Nahdiyyin dalam Tinjauan Agama dan Adat, (Jurnal Al-AdYaN, vol. VIII, no. 1, Januari-Juni 2013), hlm. 6. lama, apalagi dengan dihadapkan pada masyarakat yang buta ilmu pengetahuan. Pernah ada kasus seorang ustadz di dusun yang dekat dengan Dusun Nuguk tersebut, ia ingin mencoba merubah tradisi yang menurutnya tidak sesuai dengan syar'at Islam, termasuk shalat berjamaah maghrib-isya di rumah duka, bukan malah menuai hasil yang baik, malahan ustadz tersebut diusir oleh masyarakat setempat. Hal ini yang penulis katakan bahwa untuk merubah suatu tradisi yang sudah mendarah daging-yang mungkin secara eksplisit tidak sesuai dengan syari'at perlu proses dan waktu yang lama. ${ }^{23}$ Oleh karena itu, Sunan Kalijaga ketika mendakwakan Islam, beliau menempuh proses gradual yang mencoba memasukkan unsurunsur Islam ke dalam suatu tradisi, dan bukan dengan langsung menjustifikasi bahwa tradisi tersebut salah.

\section{Literatur Turast: Legalisasi Tradisi}

Biasanya pelaksaan suatu tradisi tidak terlepas dari resepsi dari sebuah teks, baik dari al-Qur`an maupun hadis. Namun, ada juga tradisi yang memang

\footnotetext{
${ }^{23}$ Penulis tidak mengatakan bahwa tradisi "Shalat Berjamaah Maghrib-Isya Di Rumah Duka", karena tujuan dalam penelitian ini bukan menjustifikasi 'benar-salah' suatu tradisi, namun melihat realitas serta tradisi yang berkembang dari aspek sosio-historisnya. Terutama dalam kajian Living Hadis dan al-Qur`an yang melihat realitas tradisi yang berkembang yang mungkin diilhami atau terinspirasi oleh suatu teks (hadis/al-Qur`an).
} 
dilakukan tanpa resepsi dari sebuah teks, dan merupakan suatu tradisi yang telah diproklamirkan oleh para pendahulu mereka secara turun-temurun. Dan tradisi 'Shalat Berjamaah Mahgrib-Isya di Rumah Duka' di dusun Nuguk merupakan salah satu bentuk tradisi yang diilhami oleh sebuah teks, sebagaimana yang dikatakan oleh Pak Murni:

"Tradisi tuk jo dah mulai dari lolu te am, kan aq ningo dalele "setiap tanoh arai kan panai ke besujod" jadi, apailagi ko di lamankan. ntah dari kero'an atau apai q nok kok panai" (Tradisi ini sudah dilakikan secara turun temurun, dan yang saya tau dalilnya adalah "setiap permukaan bumi dijadikan Allah sebagai tempat bersujud, jadi apalagi di rumah kan, jelas lebih boleh.”. Dan saya tidak mengetahui pasti apakah itu teks al-Qur`an atau dari teks lainnya. ${ }^{24}$

Berdasarkan keterangan dari Pak Murni di atas, bahwa redaksi makna yang beliau ucapkan boleh jadi hadis hadis berikut ini :

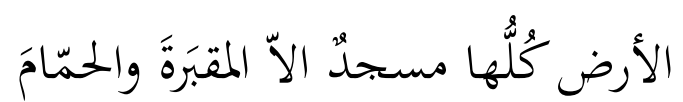

"Bumi ini semuanya merupakan masjid (tempat sujud) kecuali kuburan dan Wc" (HR. Ibnu Majah no. 737; Tirmidzi no. 236 ; dan Abu Dawud no. 415). ${ }^{25}$

\footnotetext{
${ }^{24}$ Wawancara dengan Bpk. Murni, Sabtu, 03 Maret 2018 (Pukul. 20.00 WIB).

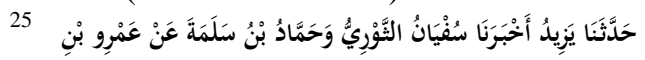

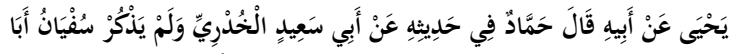

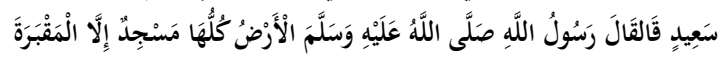

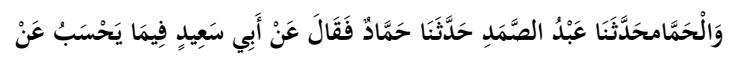

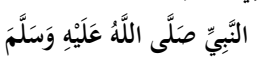

Agak sulit mendapatkan keterangan yang lebih jelas tentang teks turast yang mereka jadikan landasan dalam tradisi tersebut, penulis telah melakukan wawancara dengan beberapa masyarakat setempat, namun jawaban yang mereka suguhkan juga masih sama dengan apa yang dikataka oleh Pak Murni. ${ }^{26}$ Jadi sebagai hipotesisis sementara, redaksi yang diucapkan oleh Pak Murni memang hampir senada dengan hadis yang tercantum di atas. Dan untuk mendapat keterangan yang lebih jauh tentang genealogi pemikiran serta struktur bangunan intelektual sehingga terbentuknya tradisi tersebut sangat sulit untuk dilacak, karena beberapa informan utama telah meninggal dunia.

\section{Tradisi 'Shalat Berjamaah Maghrib-} Isya di Rumah Duka' di Dusun Nuguk: Kajian Sosiologi Pengetahuan Karl Mannheim

Sebagaimana yang telah dijelaskan di atas, bahwa dalam melihat tradisi 'Shalat

\footnotetext{
Lihat dalam CD Maktabah Shamilah. Hadis-hadis سن : الترمذي البلب ما جاء ان الارض كلها مسجد الا الجزء 2 الصفحة 31,سنن

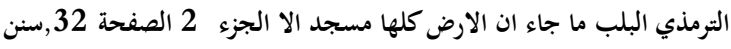
ابن ماجه البلب المواضعالتى تكره فيها الصلاة الجزء مسند احمد البلب مسند ابي سعيد اخدري رضي الله الجزء 2303 403, مسند احمد البلب مسند ابي سعيد اخدري رضي الله الجزء 23

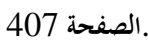

${ }^{26}$ Berikut informan yang diwawancarai : Ridwan, Minggu, 18 Maret 2018 ( $b a$ 'da Maghrib) ; Ito, Minggu, 18 Maret 2018 (pukul : 20. 00) ; Ibu Hamsiyah, Senin, 19 Maret 2018 (13.30) via telpon.
} 
Berjamaah Mahgrib-Isya di Rumah Duka' pada masyarakat Dusun Nuguk, maka akan penulis akan menganalisis dengan teori Sosiologi Pengetahuan Karl Mannheim, yang difokuskan pada tiga titik pokok, yaitu: Makna Objektif, Makna Eksprasif dan Makna Dokumenter. Adapun pengaplikasian satu persatu dari tiga poin tersebut adalah:

\section{Makna Objektif}

Makna Objektif adalah makna yang berlaku universal dan diketahui secara universal. Makna Objektif dalam tradisi 'Shalat Berjamaah Mahgrib-Isya di Rumah Duka' pada masyarakat dusun Nuguk bahwa praktik tersebut merupakan suatu tradisi yang harus dijaga dan dilestarikan oleh masyarakat setempat agar tetap eksisis karena merupakan tradisi yang telah diwarisi seara turun-temurun oleh para pendahulu mereka-terutama merupakan warisan tradisi dari para tokoh agama mereka terdahulu. Selain menjaga serta melestarikan tradisi yang telah ada, juga tradisi tersebut bertujuan untuk mendo'akan serta menghibur pihak keluarga yang ditinggalkan.

Selain itu, makna objektif dalam tradisi 'Shalat Berjamaah Mahgrib-Isya di Rumah Duka' tersebut juga merupakan bentuk apresiasi kepatuhan masyarakat dusun Nuguk terhadap para pemuka agama mereka (kyai). Karena dalam dalam pembacaan yasin dan tahlil dalam tradisi tersebut dipimpin oleh seseorang yang dianggap sebagai tokoh elite agama pada masyarakat setempat. Dan juga bukan hanya sekedar menjaga tradisi serta bentuk kepatuhan kepada para pemuka agama, namun juga tradisi tersebut sudah menjadi amalan khas dan dianggap sangat baik serta berpahala bagi yang melaksanakannya menurut masyarakat dusun Nuguk.

\section{Makna Ekspresif}

Makna ekspresif adalah makna yang diresepsi secara personal dari orangorang yang terintegrasi dalam tradisi 'Shalat Berjamaah Mahgrib-Isya di Rumah Duka' tersebut. Dan Karl Mannheim menyebutnya juga dengan aktor tindakan atau pelaku tindakan sosial. Pada pelaksanaan 'Shalat Berjamaah Mahgrib-Isya di Rumah Duka' ini, imam atau sang kyai yang menjadi aktor tindakan tunggal di dalamnya. Selain imam sebagai pelaku tindakan, adalah pihak keluarga yang ditinggalkan, serta masyarakat yang terlibat di dalamnya. Dan dari masingmasing komponen tersebut akan ditemukan diversifikasi (keragaman) makna mengenai tradisi tersebut. Sebagaimana yang dikemukakan oleh 
Bapak Murni selaku orang yang biasa memimpin yasinan dan tahlilan dalam acara tersebut :

“Kalau ditanyo' mampat dari kebiasaan tuk, je ke usaho mendo'akan mayat dan ke ngibo keluargo yang dah di dudi e mati, memang dari ato' umoh je model tuk am" (Kalau ditanya tentang manfaat serta tujuan dari tradisi ini, yang merupakan suatu bentuk usaha untuk mendo'akan mayat serta untuk menghibur pihak keluarga yang sedang berduka. Dan memang tradisi ini sudah diwarisi dari para tokoh agam terdahulu).

Demikian juga yang diungkapkan oleh Bapak Melly ia mengatakan bahwa :

"Kebiasaan tuk jo dah mulai dari lolu teh am, tapi tuk ada ado kaso, ado yang semayang ke mensiget. Dan aku nok meyalohkan tradisi model tuk, cumo dengan syarat di mensiget harus ado adzan, terutama maghrib dengan iso, nang sampai cumo ngutamokan di laman orang yang mati" (Tradisi ini memang sudah mulai dulu dilakukan, dan sekarang sudang agak lumayan karena disamping masyarakat melakukan shalat di rumah duka, dan di masjid juga tetap ada yang shalat, terutama maghrib dan isya. Dan kebiasaan seperti itu boleh saja dilestarikan, namun harus diimbangi juga ada yang shalat di masjid bukan hanya di rumah duka)

Jadi berdasarkan pendapat yang dikemukan oleh Pak Murni dan Pak Melly di atas, tentunya makna ekspresi dari tradisi 'Shalat Berjamaah MahgribIsya di Rumah Duka' tersebut memiliki berbedaan resepsi pemaknaan, baik dari segi tujuan maupun dari segi model pelaksanaannya.

3. Makna Dokumenter

Makna dokumenter adalah makna yang tersirat atau tersembunyi, sehingga aktor atau pelaku tindakan tidak menyadari bahwa apa yang dilakukannya itu merupakan suatu ekspresi yang menunjukan kepada kebudayaan secara keseluruhan. Makna dokumenter ini diperoleh dari analisa yang mendalam yang dikaitkan dengan ekstra teoritis. Dan para pelaku tindakan atau aktor dari tradisi tersebut tidak menyadari bahwa apa yang mereka lakukan merupakan bagian dari makna induk yang melatar-belakangi semua hubungan sosial yang berlangsung. Tradisi 'Shalat Berjamaah Mahgrib-Isya di Rumah Duka' di dusun Nuguk menimbulkan tiga resepsi terhadap masyarakat : Pertama, sebagai tradisi material, yaitu suatu keadaan di mana masyarakat hanya menganggap bahwa tradisi tersebut merupakan wujud tradisi yang telah ada dan dilakukan. Kedua, tradisi religius atau praktik keberagamaan, yaitu masyarakat menerima suatu keadaan apa yang mereka lakukan termasuk dalam cara beragamanya dilihat dari praktik keberagamaan. Ketiga, tradisi simbolis, yaitu masyarakat menganggap bahwa 
apa yang mereka lakukan makna yang sesuai dengan lokus yang melingkupnya.

\section{Tradisi 'Shalat Berjamaah} Mahgrib-Isya di Rumah Duka' di dusun Nuguk merupakan bentuk representasi dari ketiga resepsi yang timbul di masyarakat. Pada resepsi pertama (tradisi material), menunjukkan bahwa tradisi 'Shalat Berjamaah Mahgrib-Isya di Rumah Duka' dianggap sebagai suatu yang telah mengakar di masyarakat yang diwarisi secara turun-temurun oleh para tokot elite agama mereka sebelumnya. Sebagai praktik keberagamaan, yaitu masyarakat melihat bahwa tradisi tersebut merupakan bentuk praktik umat beragama dengan mengambil manfaat dari tradisi tersebut seperti membacakan yasin dan tahlil. Kemudian terakhir, sebagai tradisi simbolis, yaitu masyarakat menganggap bahwa dengan asbab dibacakan yasin dan tahlilan harapannya dapat menolong atau meringankan (siksaan) mayit di alam kubur.

\section{Proses Transmisi Tradisi}

Berdirinya, hidup serta bertahannya suatu tradisi tentunya tidak terlepas dari para agensi yang menjadi pelopor acuan tindakan beragama dalam suatu kelompok masyarakat. Dilihat dari kapasitas serta kemampuan agen untuk bertindak, Max Waber mengidentifikasi ada tiga tipe otoritas agen, yaitu : otoritas tradisional, otoritas kharismatik dan otoritas legalrasional. Otoritas tradisional adalah tipe agensi yang keabsahannya besandar pada adat istiadat. Otoritas kharismatik adalah tipe agensi yang disandarkan pada aspek kharisma atau kualitas istimewa seseorang, serta pengakauan orang lain terhadap kharisma tersebut, sedangkan otoritas legal-rasional adalah kekuatan serta keabsahan agensi yang ditumpukan pada legalitas atau aturan resmi, yakni kepercayaan pada prosedur. ${ }^{27}$

Dalam realitas masyarakat dusun Nuguk, tiga tipe agensi tersebut termasuk dalam karakter tokoh elit agama yang mereka jadikan acuan dalam bertindak. Kemudian terkait struktur genealogi bangunan pemikiran hingga terbentuk tradisi tersebut (Tradisi Shalat Berjamaah Mahgrib-Isya di Rumah Duka), agak sulit untuk dilacak, karena beberapa agensi sudah menginggal dunia. Sedikit memberikan informasikan dan keterangan tentang bagaimana genealogi serta proses transmisi dari tradisi tersebut berkembang, sebagaimana keterangan dari Pak Apong,

27 Kamila Adnani, dkk. Human Agent dalam Tradisi Fikih : Studi Relasi Hukum Islam dan Moralitas Perspektif Abou El Fadl, dalam Jurnal Kudifikasia : Jurnal Penelitian Keagamaan dan Sosial Budaya, Vol. 7, No. 1, Tahun 2013, STAIN Ponorogo, hlm. 4. 
beliau tidak mengetahui pasti, namun beliau memberikan sedikit keterangan bahwa, dimulainya tradisi tersebut adalah sejak beliau masih remaja dari masa Ato'Dawin yang merupakan tokoh agama masyarakat Nuguk yang cukup dikenal luas saat itu, kemudian 'ditularkan' kepada Ato' Syahri, selanjutnaya sampai pada Pak Murni yang dianggap sebagai tokoh elite agama masyarakat setempat saat ini. Pak Murni juga tidak begitu mengetahui tentang awal mula mengapa tradisi itu bisa terbentuk - apakah awalnya hanya tahlil dan yasinan yang kemudian dimodifikasi sehingga terbentuk tradisi demikan, dan keterangan ini belum bisa didapat. ${ }^{28}$

\section{KESIMPULAN}

Tradisi 'Shalat Berjamaah Mahgrib-Isya di Rumah Yang Berduka selama 7 hari' di Dusun Nuguk, Melawi, Kalimantan Barat adalah suatu tradisi yang telah dilakukan secara turun-temurun oleh masyarakat setempat, dengan prosesi melakukan shalat berjamaah maghrib dan isya', setelah maghrib melakukan pembacaan Yasin dan setelah isya dilanjutkan dengan membaca tahlil dengan dipimpin oleh seorang tokok elite agama setempat (kyai). Adapun teks yang mengilhami praktik tradisi tersebaut menurut redaksi dari Pak Murni adalah hadis yang mengatakan bahwa "Bumi ini semuanya merupakan masjid (tempat sujud) kecuali kuburan dan Wc" (HR. Ibnu Majah no. 737).

Dalam perspektif teori Sosiologi Pengetahuan dari Karl Mannheim, maka tradisi Tradisi 'Shalat Berjamaah MahgribIsya di Rumah Yang Berduka selama 7 hari' di Dusun Nuguk, Melawi, Kalimantan Barat dapat dirincikan sebagai berikut : 1). Makna Objektif semua masyarakat meyakini tradisi yang mereka lakukan adalah warisan dari pada pendahulu mereka, 2). Makna Ekspresi mereka meyakini dengan fadhilah dengan dibacakan yasin dan tahlil dapat menolong mayat di alam kubur, dan 3). Makna Dokumenter adalah mereka tidak menyadari makna yang tersirat atau tersebunyi di dalam tradisi tersebut, sehingga aktor atau pelaku tindakan tidak menyadari bahwa apa yang dilakukannya itu merupakan suatu ekspresi yang menunjukan kepada kebudayaan secara keseluruhan.

Terakhir, proses transmisi tradisi; adapun agen-agen yang berpengaruh dalam tradisi tersebut adalah Ato'Dawin (sebagai agensi pertama) kemudian 'ditularkan' kepada Ato' Syahri (agensi kedua), selanjutnya sampai pada Pak Murni yang dianggap sebagai tokoh elite agama masyarakat setempat saat ini.

\footnotetext{
${ }^{28}$ Wawancara dengan Pak Apong, Selasa, 06-03-2018 (pukul : $20.30 \mathrm{WIB}$ ).
} 


\section{DAFTAR PUSTAKA}

Adnani, Kamila. dkk. Human Agent dalam Tradisi Fikih : Studi Relasi Hukum Islam dan Moralitas Perspektif Abou El Fadl, dalam Jurnal Kudifikasia : Jurnal Penelitian Keagamaan dan Sosial Budaya, Vol. 7, No. 1, Tahun 2013, STAIN Ponorogo

Baum, Gregory. Agama dalam bayangbayang relativisme : Agama, Kebenaran dan Sosiologi Pengetahuan, terj. Ahmad Murtajib Chaeri dan Asyhuri Arow. Yogyakarta : PT. Tiara Wacana Yogya, 1999.

Budiwanti, Erni. Islam Sasak : Wetu Telu Versus Waktu Lima. Yogjakarta : LkiS, 2000.

Buku Pedoman Desa Tebing karangan tahun 2017

CD Maktabah Shamilah.

Fanani, Muhyar. Metode Studi Islam: Aplikasi Sosiologi Pengetahuan Sebagai Cara Pandang . Yogyakarta : Pustaka Pelajar, 2008.

Hariwijaya, M. Metodologi Teknik penulisan Skripsi, Thesis dan Disertasi.Yogjakarta : Almatera Publishing, 2007.

Hidayat, Komariddin. Psikologi Kematian. Jakarta : Puri Mutiara, 2005.

HS, A. Syihabuddin. Tradisi Upacara Kematian Pada Masyarakat Nahdiyyin dalam Tinjauan Agama dan Adat. Jurnal Al-AdYaN, vol. VIII, no. 1, Januari-Juni 2013.

Jauhari,Heri.Panduan Penulisan Skripsi Teori dan Aplikasi. Bandung : Pustaka Setia ,2010.

Karim, Abdul. Makna Kematian dalam Perspektif Tasawuf. Jurnal
ESOTERIK, vol. 1, no. 1, Juni 2015, STAIN Kudus Jawa Tengah.

Koentrajaningrat. Ritus Peralihan di Indonesia, cet. 2. Jakarta : Balai Pustaka, 1993.

Moh. Khairuddin. Tradisi Slametan Kematian dalam Tinjauan Hukum Islam dan Budaya. Jurnal Penelitian Keislaman, vol. 11, no. 2, Juli 2015, UIN Syarif Hidayatullah Jakarta.

Shihab, M. Quraish. Perjalanan Menuju Keabadian. Tanggerang : Lentera Hati, 2001.

Suwito, (dkk). Tradisi Dan Ritual Kematian Wong Islam Jawa. Jurnal Kebudayaan Islam, vol. 13, no. 2. Juli - Desember, 2015, IAIN Purwokerto.

Tim Penerjemah. Al-Qur'an dan Terjemah Bahasa Dayak Kanayatn. Jakarta : Puslitbang LKK Badan Litbang dan Diklat Kementerian Agama RI, 2015.

Ulya, Ibrizatul. Pembacaan 124.000 Kali Surat Al-Ikhlas Dalam Ritual Kematian Di Jawa (Stusi Kasus di Desa Sungonlegowo, Bungah, Gresik, Jawa Timur). Fakultas Ushuluddin dan Pemikiran Islam, UIN Sunan Kalijaga Yogjakarta, 2016.

Widyawati, Pembacaan 100.000 Kali Surat Al-Ikhlas Dalam Ritual Kematian Di Jawa (Rw. 03 Kelurahan Pulutan, Sidorejo, Salatiga, Jawa Tengah). Fakultas Ushuluddin dan Pemikiran Islam, UIN Sunan Kalijaga Yogjakarta, 2017.

Yusa,I Made Marthana. Perayaan Kematian dalam Tinjauan Desain dan Gaya Hidup. Jurnal Studi Kultural, vol. II, no. 2, Juli 2017. 